\title{
Mental health care in the territory: conceptions of primary health
} care professionals

\author{
O cuidado em saúde mental no território: concepções de profissionais da atenção básica
} El cuidado en salud mental en el territorio: concepciones de profesionales de la atención primária

Elisangela Costa de Oliveira ${ }^{1}$

Ana Tereza de Medeiros ${ }^{1}$ Flávia Maiele Pedroza Trajano ${ }^{1}$

Gabriel Chaves Neto ${ }^{1}$

Sandra Aparecida de Almeida ${ }^{1}$ Luana Rodrigues de Almeida ${ }^{1}$

1. Federal University of Paraíba. João Pessoa, PB, Brazil.

Corresponding Author:

Gabriel Chaves de Neto

E-mail: gabrielchavesufpb@hotmail.com

Submitted on $02 / 18 / 2017$.

Accepted on 04/25/2017.

DOI: 10.1590/2177-9465-EAN-2017-0040

\section{Abstract}

This study aimed to analyze the conceptions that guide the practices of professionals in relation to care provided in mental health This qualitative study enrolled professionals from a government health clinic in João Pessoa, Paraiba, Brazil. Data collection was conducted through a semi-structured interview during which the testimonies were recorded and subsequently transcribed in full. Analysis of the speech used Fiorin's Critical Theory, which allowed the elaboration of two subcategories: "Knowledge that guides practices in mental health" and "The invisibility of the integrating character of the Family Health Strategy from the Network of Psychosocial Care perspective". The focus of nursing care and health must not be bound only to the sickness, but caring practices should be transformed to promote comprehensive care and the resocialization of the person with psychic suffering.

Keywords: Care; Nursing; Mental Health; Primary Care.

\section{Resumo}

Este estudo teve como objetivo analisar as concepções que norteiam as práticas dos profissionais em relação aos cuidados em Saúde Mental. Trata-se de uma pesquisa de abordagem qualitativa, desenvolvida com profissionais de uma Unidade de Saúde do Município de João Pessoa-PB. A coleta de dados foi realizada por meio de um roteiro de entrevista semiestruturado, com os depoimentos gravados e, posteriormente, transcritos na sua íntegra. Foi realizada a análise do discurso, conforme a Teoria Crítica proposta por Fiorin, que permitiu elaborar as subcategorias: Saberes que norteiam as práticas em Saúde Mental e A invisibilidade do caráter integrador da Estratégia de Saúde da Família na perspectiva da RAPS. Foi possível concluir que o enfoque do cuidar em enfermagem e na saúde não deve estar vinculado apenas à doença, uma vez que, as práticas assistenciais precisam ser transformadas a fim de promover um cuidado integral e a ressocialização da pessoa em sofrimento psíquico.

Palavras-chave: Cuidado; Enfermagem; Saúde Mental; Atenção Primária.

\section{Resumen}

Objetivo: Analizar las concepciones que orientan las prácticas de los profesionales en relación a los cuidados en Salud Mental. Método: Investigación cualitativa, desarrollada con profesionales de una Unidad de Salud del municipio de João Pessoa, PB. La recolección de datos fue realizada por medio de un guión de entrevista semiestructurado, con los testimonios grabados y posteriormente transcritos en su totalidad. Resultados: Se realizó el análisis del discurso, conforme la Teoría Crítica de Fiorin, que permitió elaborar las subcategorías: Saberes que orientan las prácticas en Salud Mental y La invisibilidad del carácter integrador de la Estrategia de Salud de la Familia en la perspectiva de la RAPS. Conclusión: El enfoque del cuidar en enfermería y en la salud no debe estar vinculado sólo a la enfermedad, ya que las prácticas asistenciales necesitan ser transformadas a fin de promover un cuidado integral y la resocialización de la persona en sufrimiento psíquico.

Palabras clave: Cuidado; Enfermería; Salud Mental; Atención Primaria. 


\section{INTRODUCTION}

Since the 1970s, the movement for psychiatric reform has criticized the traditional model of hospital-centered care and defended the viewpoint that mental health care should be integrated into the community care system, a guideline that the new Brazilian National Healthcare System (SUS) presented for general health. As primary care is the first level of this system, we defend the argument that it is in the clinics of the Family Health Strategy (FHS) that mental health care needs to find the possibility of acceptance, integration, structuring and development.

The change from the traditional institutionalized, curative and exclusionary perspective to the new vision of territorial, community-based interventions aimed at promoting well-being related to biological and psychological existence and social inclusion allows mental care that visualizes the overcoming of the historical lack of care and abuse and potentiates the construction of new spaces for knowledge, and social, political and legal interventions.

In the 1970s and 1980s and contemporary to the movement of criticism and transformation represented by psychiatric reform, the World Health Organization (WHO) recognized the magnitude of mental health problems and admitted that it is impossible that care of the mentally ill can be carried out exclusively by specialists in psychiatry. Thus, the decentralization of existing services began to be advocated with the integration of psychiatric services into general care clinics, the training of non-specialized caregivers as well as increasing community participation. ${ }^{1}$

In this perspective, the Brazilian Ministry of Health through the National Mental Health Policy proposed an integrated and expanded mental health services network to care for people with mental disorders. This Psychosocial Care Network (PCN), instituted by ordinance No. 3,088 of December 23, 2011 has the purpose of creating, expanding and articulating health care points for people suffering mentally or with disorders and needs arising from the use of crack, alcohol and other drugs within the SUS setting. ${ }^{2}$

The role of primary care services is important to the implementation of the basic principles of psychiatric reform for social inclusion in order to achieve integrality and meet the territoriality requirement of care recommended by the SUS. ${ }^{3}$ Primary care is one of the components of the PCN; this is the gateway for all SUS users, since it is in the FHS that the commitment and co-responsibility bonds are established with the population based on an expanded perspective of the way of life, health and illness within family and cultural contexts. ${ }^{4}$

By working in the FHS, it is possible to recognize and address risk factors to which the community is exposed using established relationships between different social and institutional segments, aiming to deal with situations that transcend the specificity of the health sector and have decisive effects on the living and health conditions of individuals, families and the community. ${ }^{4}$

Besides these possibilities, the epidemiological dimension is a factor that justifies the development of mental health care and actions within primary care. According to Cabral \& Albuquerque, based on data of the Ministry of Health, 22 to $25 \%$ of users served by the family health teams present mental disorders and require comprehensive and continued care. In fact, all users need care in respect to mental health. ${ }^{5}$

In view of this, the Brazilian Ministry of Health states that new practices should be structured for care teams, seeking to humanize actions performed in order to obtain user satisfaction through a close relationship between the professionals and the community. ${ }^{1}$ Thus, the FHS is considered to be one of the fundamental devices for mental health care and mental health measures in the territory and hence it can be seen as the most promising way to mobilize community resources and implement psychiatric reform. ${ }^{3,6}$

Considering the importance of primary care to implement the transformations required to ensure the effectiveness of psychiatric reform, and considering that work processes are guided by knowledge, one of the instruments of this work, we asked:

\begin{abstract}
What is the knowledge that guides professional practices in the primary care of mental health and are manifested in the conceptions of the themes: the mental health-illness process, importance of the FHS in mental health care and its articulation within the PCN?
\end{abstract}

In order to broaden our understanding on the issue, this research had the general objective of analyzing the conceptions that guide the practices of professionals in relation to mental health care in the context of psychiatric reform in the FHS. For this, we sought to identify the professionals' knowledge about the theoretical assumptions of mental health and to identify the meaning that the FHS represents within the PCN.

\section{METHODS}

This qualitative interpretative study used Critical Discourse Analysis theory. Qualitative research is concerned with a level of reality that cannot be measured, in this case, conceptions, meanings and knowledge that guide the professionals' performance in the management of mental health care in the FHS from the perspective of psychiatric reform. This type of methodological approach corresponds to a deeper space of relationships, processes and phenomena that cannot be reduced to an alterable instrument. Hence, it investigates aspects that appreciate the values, beliefs and experiences that permeate human relationships. ${ }^{7}$ In this sense, it is justified to use Critical Discourse Analysis from Fiorin's perspective, for whom text expresses the worldview of people. ${ }^{8}$ Thus, by analyzing testimonies, it is possible to perceive what is hidden and to identify the knowledge that guides the professional's practice in respect to mental health in primary care in their conception.

This research was carried out in the form of interviews conducted by a nurse who, together with the other researchers 
of this study, is part of the practice and research area of Mental Health Nursing. The ties with the study field had already been constructed by curricular internships of students and with previous research on the subject of mental health and gender. Thus, there was already a link between the researchers and the participating staff, which facilitated the development of the research, as all the FHS team, the participants of this study, knew the researchers' interest in strengthening mental health care in primary care.

The study setting was a family health clinic located in the municipality of João Pessoa, Paraíba, Brazil. Sixteen professionals of the basic healthcare team were intentionally selected and interviewed from August to October of 2016. The study participants were five men and 11 women, with a mean age of 40 years comprising two nurses, one physician, one dentist, one nursing technician, one oral health assistant and ten health workers, who had worked in the family health clinic for at least three months.

A semi-structured interview was used for data collection and for the production of empirical material. A script was used to support the study and stimulate the participants to speak freely about the issue under study from a line of reasoning and experiences. The following items were investigated:

A) What do you understand by mental health (illness)?

B) How do you see the insertion of the person with a mental disorder in the community?

C) How do you see the importance of the FHS as a component of the PCN?

D) How does the team perform mental health actions with the community/users of the services?

E) How do you act in situations that require mental health care?

F) What support does the Family Health Support Center (FHSC) provide in this process?

G) What are the facilitators and difficulties encountered to carry out these actions?

The interviews took place in the health clinic, the setting of the study, in a private room with only one participant at a time in order to guarantee confidentiality and allow more freedom for the interviewee to express their opinions. The interviews lasted an average of 40 minutes. Because this is a qualitative research that does not intend to produce generalizations from samples, the number of participants in the research was defined based on data saturation, that is, the interviews stopped when the researchers perceived that the meanings began to be repeated without adding to the previously gathered empirical material. All the professionals invited to participate in the research collaborated in an attentive and spontaneous way.

All testimonies were recorded, transcribed in their entirety and organized in blocks of meanings, around the central issues after the participant had signed an informed consent form.
Analysis of the empirical material allowed the construction of two subcategories: 1) Knowledge that guides practices in mental health and 2) The invisibility of the integrating character of the FHS from the PCN perspective.

The research was authorized by the Municipal Secretariat of João Pessoa through the Health Education Department and the Research Ethics Committee of the Health Sciences Center (\# CAAE 55986616.0.0000.5188). The norms related to research with Humans of the National Health Council (Law $n^{\circ} 466 / 12^{9}$ ) were respected. The research participants were coded by the letter "I" followed by a number corresponding to the order of their interview to guarantee their privacy, that is, the first interviewee was I1, the second, 12 and so on.

\section{RESULTS AND DISCUSSION}

\section{Knowledge that guides mental health practices}

When questioned about the knowledge that guides mental health care practices in the territory, the interviewees expressed conceptions about the categories that informed their positions about the possibilities/limitations of a transforming perspective for mental health care.

Concepts related to mental health/illness demonstrate the fragmented understanding of the health/disease process established by the dichotomy between body and mind; in the perspective of psychiatric reform, health and illness are understood as a process. There is an attempt to approach at least two areas of mental health, biological and psychological, in the following statements:

[...] It is when you are in complete well-being. Physical, which includes the psychological, right? I think mental health is you feeling well in a general way. Especially in mental conditions. Your good and perfect mental conditions $[. .$.$] (I8)$

[...] Well, mental health, it can be the complete person, full power, complete, mental health well, normal, conscious $[\ldots](\mid 11)$

However, the complexity of the mental health area, its intersectoriality and transversality of knowledge, requires the widening of borders to include health and disease as a process that transcends the biological dimension because it also originates in the historical, social and cultural setting of processes throughout the existence of mankind. ${ }^{10}$

With a view to transforming mental health practices, in order to meet the demands of the current psychiatric reform, besides knowledge - which is one of the instruments of the work - there must also be a redefinition of the work object in mental health. Classical psychiatry took mental illness as its object, and when it considered illness as a natural object, external to subjects, it ignored all the experiences of the person in a situation of psychic suffering. By adopting the model of the natural sciences to explain 
subjectivity, psychiatry ended up objectifying the subject and human experience. ${ }^{11,12}$

These positivist relationships established between the mad and madness mark the institutionalized, medicalizing and excluding care model that characterizes psychiatry. However, the field of mental health, in particular psychosocial care, must consider the person in psyche or mental suffering by valuing their life experience; the object of work must stop being the disease and become human existence and its subjectivities. ${ }^{12,13}$

To recognize and accept this new object of work, professionals need to recognize that psychosocial issues are just one part of the whole that represents the extent of mental health. Moreover, the very definition and recognition of these concepts mental disorder and illness - also depend on the social, cultural, economic and legal contexts of different societies. ${ }^{14}$ Therefore, it is not possible to limit the understanding of mental health to the absence of what are commonly termed serious mental disorders such as schizophrenia, depression and bipolarity, among others. This can be seen in the following statements, when interviewees recognize mental health as the absence of disorders when asked about the meaning of health and mental illness:

[...] It is like the person, if you have any health problems, of health: depression, schizophrenia, insomnia, too, right? Basically, just this. [And mental illness?] Depression and schizophrenia [...] (I2)

[...] For me it is an individual who has a psychological disorder. [And the mental illness?] this is the same thing, no? [...] (16)

[...] It is every disorder that affects the balance of the nervous system, neurovegetative, right? Disorder, a dysfunction. Anxiety, depression. It is the euphoria, hysteria, everything is a disorder that is included in what is called mental health, right? [...] (17)

As care practices are guided by instrumental technical knowledge, the changes that are intended from the movement for psychiatric reform necessarily need new knowledge and practices. Without this transformation, we will have new services that work with the same logic as traditional psychiatry in view of the difficulty of redirecting work processes. For as we reorient the knowledge and the object of attention to focus on the person, on his experiences and on his suffering - not just on his illness - we will have a service with the potential to overcome the paradigm. Services that prioritize the mental illness are spaces of repression, discipline, control and exclusion. Whereas services that deal with the individuals as social beings are spaces of sociability, listening, welcoming, caring, inclusion and emancipation. This is the notion of integrality in the mental health field and psychosocial care that is intended to be seen as a paradigmatic achievement.

In this context, primary care professionals need to be aware that mental health care, in addition to the demands generally focused on the disease alone, should identify mental health needs. Only then, the person who needs the care will not be considered a function of his disease, excluding all the other factors that contribute to this illness. ${ }^{15}$

The FHS is a powerful mental health care network device to promote the radical nature of deinstitutionalization proposed by the movement leading psychiatric reform, to allow community care and in the territory, centered on people in their social and family contexts.

However, because they exclusively define mental illness as the objects of work, the professionals of this service show stereotyped conceptions and express the categories, danger and fear, still very much associated with 'mental illness' in the conception of classical psychiatry. This is illustrated in the testimonies that follow, when the interviewees were questioned about the possibilities and strategies for promoting social insertion of the person with mental disorder in society:

[...] No, I see normal now, provided there are criteria. Because a person with any mental disorder can potentially become a dangerous person, because no one knows what is going on in his world, right? [...] (11)

[...] As mental illness is a ..., it is a disease that frightens. It frightens the family, it scares the patient himself, it scares the professionals, some professionals who do not know how to deal with it, so it's a very difficult thing, so to put it into practice $[. .].(18)$

Thus, professionals fear the reception of and caring for people suffering mentally. These conceptions and the practices guided by them delay necessary advances in psychiatric reform, such as overcoming the traditional paradigm and services with this focus compromise the structure of the PCN.

The user with mental health needs has the right to a dignified service with individual reception and qualified listening that improve the scope of comprehensive care. However, the mental health actions carried out by primary care teams are limited to referrals to the specialized sector - often without follow-up of the cases - and to the transcription of prescriptions and dispensing of psychoactive drugs, reinforcing practices that need to be overcome to achieve the principles of psychiatric reform.

Considering these limits of the FHS within the PCN, we identified the second subcategory.

\section{The invisibility of the integrating character of the FHS in the perspective of PCN}

Studies carried out on family health teams focusing on mental health and psychosocial care show that the intentions of public mental health policies are not very effective in the day-today life of services, resulting in the invisibility of the demands and needs of mental health in these services. ${ }^{14-16}$ However, primary care services are devices capable of interdisciplinary practices and intersectoral actions within the family context involving the territory of individuals. Their ability to articulate in a network 
facilitates the promotion of comprehensive care that enhances the quality of life of people who experience psychic suffering.

For some interviewees in this study, recognition of the importance that the FHS can have in consolidating psychiatric reform is impaired because of the invisibility of the PCN. This means that articulation between services seems to be lacking since, by definition, the PCN will only exist effectively when it is interconnected with other health services. The procedural and dynamic links of PCN reveal the complexity that must be considered in mental health care with this new perspective.

With this approach, the testimonies about the understanding of the mental health category reveal that, one specialty cannot cover its vastness because of all the interconnections:

\section{[...] The follow-ups here of people who have mental problems or problems with mental health, they come to refill their prescription and an accompaniment to this effect, to refill the prescription and consult with a doctor and ask for a referral to go to a psychiatrist [...] In the event of a crisis, we refer them to the CAPS [...] (I8) \\ [...] CAPS, right? That is the Psychosocial Care Center. There are psychologists there to have a, a conversation [...] (I13)}

From the testimony of interviewee 18 , it is obvious that the services need to be publicized and their vocations and purposes known by the members of the teams. In this case, it would not be a Psychosocial Care Center (CAPS) to be referenced in an acute crisis, but, according to the organization of the network, patients should be referred to the psychiatric emergency service.

According to ordinance No. 366 of February 19, 2002, which regulates the CAPS ${ }^{17}$, and ordinance No. 3,088 of 2011, which establishes the $\mathrm{PCN}^{18}$, CAPS is an open service with a multiprofessional team that provides care to the population. This care includes clinical follow-ups on a daily basis to avoid psychiatric hospitalization, strengthening social reintegration of users in their community, promoting articulation with other services within the network, regulating the gateway to mental health care, providing support with mental health care in the basic network, among with other fundamental actions that give significance to psychiatric reform in Brazil.

Together with the FHS, CAPS became strategic services within the process of deinstitutionalization, as they are articulation tools of the mental health care network. For this, the CAPS should provide matrix support to primary care teams. This matrix support should conduct mental health cases, supporting the team's actions, helping them to conduct interventions with maximum success, avoiding referrals to the more complex levels of resources.

To facilitate this articulation, one of the strategies advocated by the Brazilian Ministry of Health was the creation of the FHSC, which is regulated by Ordinance No. 2,488, dated October 21, 2011. The FHSC is configured with multiprofessional teams that work together with family health teams and primary care teams, thus contributing to increase the care capacity of the interlinked teams, helping them to solve problems and manage certain situations. ${ }^{19}$

In mental health, the FHSC functions as a multiprofessional rearguard of care, providing technical-pedagogical support (permanent education in health) to the FHS, interpersonal bonds and institutional support in the process of collectively constructing therapeutic projects with professionals and the population.

However, when questioned in relation to FHSC activities, the interviewees acknowledge their importance and also exposed some difficulties and misconceptions regarding their structuring and their attributions, especially in respect to technical and pedagogical support:

[...] When we had a psychologist who was supportive, it was precisely at this time that she brought the CAPS staff to hold meetings here with us, to show us, for us to know, to clarify doubts, right? To show the services, the networks, where they were installed [...] (I8)

[...] FHSC here was always to see if the health care agent or health care worker was signing in. I never worked as FHSC, there is no work with FHSC at the health clinic $[. .].(113)$

The mental institution model has the asylum as the social place of the mad and madness. All places that reproduce the logic of social exclusion of people, typical of the traditional, biomedical and exclusively curative psychiatric model are outdated due to their characteristics of control, vigilance, medicalization, punishment and repression. As a substitute, Law 10.216 of April 2001 determined the establishment of substitute services to mental health institutions, such as therapeutic residences, the availability of beds in general hospitals for the population in need of emergency psychiatric services, CAPS and community devices such as the FHS. ${ }^{20}$

The new proposal, under construction, presents itself as a dialectical process, that is, that deals with the permanent transformation of a complex and open social system that can resort to any device of the community and that has a long path to walk and a great scope to expand its action that will allow its maturation and its consolidation. This means that the impact of this PCN must transcend the biological dimension and affect the existence and daily life of people with mental health needs. Thus, the constitution of the PCN can allow paradigmatic achievements: the deinstitutionalization of the mad, of madness and any other device that promotes the institutionalization of people.

The possibility of a qualitative leap that translates as a paradigm shift in the care model for the mad and madness is the utopia that inspires professionals committed to stressing the importance of rethinking the transformations necessary in the sociocultural field related to conceptions of mental illness to produce a more welcoming attitude toward difference. ${ }^{21}$ This new approach shifts the axis of the specialties - so defended in modernity - to the perspective of transdisciplinarity. Thus, care for 
the person with mental health needs can be thought of by any professional who is invited to dialogue with life, with the world of difference, of human existence that can be endured with suffering, joys, and finally life.

\section{FINAL CONSIDERATIONS}

This study sought to understand the conceptions that guide the practices of health professionals about mental health care in primary care, from the perspective of psychiatric reform. This approach shows that the professionals' conceptions regarding mental health still refer to the absence of a serious mental illness/ disorder, an idea based exclusivity on the biological dimension to the detriment of the multiplicity of factors of reality such as subjective issues and other social dimension aspects in which subjects are involved.

In order to favor the new model proposed as psychiatric reform, it is necessary to consider the difficulties of relating to and promoting a welcoming service to users with biopsychosocial problems as reported by professionals and to understand that at the beginning the recognition of new devices such as the PCN can still be confused with services such as CAPS. Misunderstandings can occur because the CAPS were the first service of the Network to be constituted as a substitute for mental institutions and thus their importance in this respect must be recognized. However, their effectiveness as a new device derives from their interconnection in the network with other community services such as the FHS, therapeutic residences, and general hospitals, among others. This new model differs from both the mental institution spaces of classical psychiatry and the care they offer to the mad and to the approach attributed to madness.

Still in the perspective of the changes in progress, this study shows the fragility of FHSC that reverberates in the care to users with mental health needs. According to the testimonies, matrix support needs more attention in order to offer technical and pedagogical support to professionals through permanent health education and institutional support in the sense of developing therapeutic projects involving professionals and the population.

Therefore, it is imperative that the interest of mental health be directed to the subject and to their life experience, so that there are changes of practices, surpassing those guided by the mental institute attitude that excludes and stigmatizes. It is also worth noting that in addition to changing the knowledge and practices developed by professionals, including nurses, changes are required in the way society understands madness so that we have more welcoming attitudes towards differences, in order to promote comprehensive care in health and the resocialization of people in situations different to the established norms.

\section{REFERENCES}

1. Campos Junior A, Amarante PDC. Estudo sobre práticas de cuidado em saúde mental na Atenção Primária: o caso de um município do interior do estado do Rio de Janeiro. Cad. saúde colet. [internet]. 2015 [cited 2017 Jan 11]; 23(4): 425-35. Available from: http://www.scielo.br/scielo. php?pid=S1414-462X2015000400425\&script=sci_abstract\&tlng=pt
2. Ministério da Saúde (BR). Secretaria de Atenção à Saúde. Departamento de Atenção Básica. Núcleo de Apoio à Saúde da Família / Ministério da Saúde, Secretaria de Atenção à Saúde, Departamento de Atenção Básica. Brasília: Ministério da Saúde, 2014.116 p.

3. Souza LGS, Menandro MCS, Couto LLM, Schimith PB, Lima RP. Saúde Mental na Estratégia Saúde da Família: revisão da literatura brasileira. Saúde Soc. [internet]. 2012 [cited 2017 Jan 15]; 21(4): 1022-34. Available from: http://www.scielo.br/scielo.php?pid=S0104$12902012000400019 \&$ script=sci_abstract\&tIng=pt

4. Dimenstein M, Severo AK, Brito M, Pimenta AL, Medeiros V, Bezerra E. O Apoio Matricial em Unidades de Saúde da Família: experimentando inovações em saúde mental. Saúde soc. [internet]. 2009 [cited 2017 Jan 12]; 18(1): 63-74. Available from: http://www.scielo.br/scielo. php?pid=S0104-12902009000100007\&script=sci_abstract\&tlng=pt

5. Cabral TMN, Albuquerque PC. Saúde mental sob a ótica de Agentes Comunitários de Saúde: a percepção de quem cuida. Saúde debate [internet]. $2015 \mathrm{Jan} /$ Mar [cited 2017 Jan 10]; 32(104): 159-71. Available from: http://www.scielo.br/pdf/sdeb/v39n104/0103-1104sdeb-39-104-00159.pdf

6. Ribeiro LM, Medeiros SM, Albuquerque JS, Fernandes SMBA. Saúde mental e enfermagem na estratégia saúde da família: como estão atuando os enfermeiros?. Rev Esc Enferm USP [internet]. 2010 [cited 2017 Jan 10]; 44(2): 376-82. Available from: http://www.scielo.br/scielo. php?script=sci_arttext\&pid=S0080-62342010000200019

7. Minayo MCS. O desafio do conhecimento: pesquisa qualitativa em saúde. Husitec 12th ed., São Paulo. 2010. 406 p.

8. Fiorin JL. Linguagem e Ideologia. 8th ed. Ática, São Paulo. 2007.85 p.

9. Ministério da Saúde (BR). Conselho Nacional de Saúde. Resolução ${ }^{\circ}$ 466, de 12 de dezembro de 2012. Aprova normas regulamentadoras de pesquisas envolvendo seres humanos. Brasília: Diário Oficial da União, Brasília (DF), 13 jun 2013: Seção 1. Página 59.

10. Amarante P. Saúde mental e atenção psicossocial. Editora Fiocruz, Rio de Janeiro. 2007. 120 p.

11. Amarante Paulo DC. Loucura, cultura e subjetividade. Conceitos e estratégias, percursos e atores da Reforma Psiquiátrica Brasileira. In: (S. Fleury, Org.) Saúde e Democracia: a luta do CEBES. Lemos Editorial, São Paulo. 1997. 324 p.

12. Ministério da Saúde (BR). Secretaria de Atenção à Saúde. Departamento de Atenção Básica. Cadernos de atenção básica. Diretrizes do NASF, Núcleos de Apoio à Saúde da Família. Versão preliminar. Brasília, DF, 2009. $160 \mathrm{p}$.

13. Silva ATMC. A Reforma Psiquiátrica em João Pessoa-PB: limites e possibilidades de transformação do trabalho para produzir saúde mental. [Tese de doutorado] [Internet] Universidade de São Paulo. Escola de Enfermagem, São Paulo. 2003.180 pp. Available from: http:// bases.bireme.br/cgi-bin/wxislind.exe/iah/online/?IsisScript=iah/iah.xis $\& s r c=$ google\&base=LILACS\&lang=p\&nextAction=Ink\&exprSearch=3 44416\&indexSearch=ID

14. Aosani TR, Nunes KG. A saúde mental na atenção básica: a percepção dos profissionais de saúde. Rev. Psicol. Saúde [internet]. 2013 Jul/Dec [cited 2017 Jan 09]; 5(2):71-80. Available from: http://pepsic.bvsalud. org/pdf/rpsaude/v5n2/v5n2a02.pdf

15. Moliner J, Lopes SMB. Saúde mental na atenção básica: possibilidades para uma prática voltada para a ampliação e integralidade da saúde mental. Saude soc. [internet]. 2013 Out/Dec [cited 2017 Jan 12]; 22(4),1072-82. Available from: http://www.scielo.br/scielo. php?script=sci_arttext\&pid=S0104-12902013000400010

16. Correia VR, Barros S, Colvero LA. Saúde mental na atenção básica: prática da equipe de saúde da família. Rev. Esc. Enferm. USP [internet]. 2011 [cited 2017 Jan 14]; 45(6):1501-1506. Available from: http://www.scielo.br/scielo.php?script=sci_arttext\&pi $d=S 0080-62342011000600032$

17. Ministério da Saúde (BR). Portaria n. $.336 / G M$ de 19 de fevereiro de 2002 (BR). Estabelece CAPS I, CAPS II, CAPS III, CAPS i e CAPS ad. Diário Oficial da União, Brasília (DF), 19 Feb 2002.

18. Ministério da Saúde (BR). Portaria n. $-3.088 / G M$ de 23 de dezembro de 2011(BR). Institui a Rede de Atenção Psicossocial para pessoas 
com sofrimento ou transtorno mental e com necessidades decorrentes do uso de crack, álcool e outras drogas, no âmbito do Sistema Único de Saúde (SUS). Diário Oficial da União, Brasília (DF), 26 dez 2011.

19. Ministério da Saúde (BR). Portaria no 2.488/ GM de 21 de outubro de 2011 (BR). Estabelece a revisão de diretrizes e normas para a organização da Atenção Básica, para a Estratégia Saúde da Família (ESF) e o Programa de Agentes Comunitários de Saúde (PACS). Diário Oficial da União, Brasília (DF), 24 out 2011.
20. Ministério da Saúde (BR). Portaria n 10.216 de 06 de abril de 2001 . Dispõe sobre a proteção e os direitos das pessoas portadoras de transtornos mentais e redireciona o modelo assistencial em saúde mental. Diário Oficial da União, Brasília (DF), 09 Apr 2001.

21. Yasui S. Rupturas e encontros: desafio da Reforma Psiquiátrica Brasileira. Rio de Janeiro: Fiocruz, 2010. 192 p. 